\title{
PENGARUH FOOD MASSAGE TERHADAP KUALITAS TIDUR PADA LANSIA DI PANTI WREDHA DHARMA BAKTI KASIH SURAKARTA
}

\author{
Dwi Ariani, Suryanti \\ Poltekkes Kemenkes Surakarta Jurusan Keperawatan
}

\begin{abstract}
Background: Sleep disorders the elderly in the Panti wredha Dharma Bhakti Kasih Surakarta can result in impaired immune function, decrease respiratory muscle capacity, disruption of metabolic system, disruption of central nervous system regulation and psychological condition of patients impacting on long treatment period. Foot Massage is one of the complementary therapies that is considered safe and easy to administer and has the effect of improving circulation, removing the rest of the metabolism, increasing the range of motion of the joints, reducing the pain, relaxing muscles and providing comfort to the patient. The purpose of this study is to identify differences inthe effect of sleep quality score on control and treatment groups. Methods: This quasi experimental study used a control group and a treatment group where each group performed a pretest and posttest assessment. The sample size was 40 patients. Sleep quality instrument used Richard Campbell Sleep Questionnaire (RCSQ). Data were analyzed by paired t test and unpaired t test. Results: The results showed that there was no significant difference in sleep quality. while in the treatment group, showed that there was a significant difference on sleep quality The difference of sleep quality score in control group and treatment group was significantly. Conclusion: Therefore, it can be concluded that sleep quality scores in the intervention group were higher than in the control group, thus foot massage is suggested to be used as evidencebased in hospitals as one of the complementary therapies that can be used as self-care interventions to help overcome patients with critical sleepdisorder.
\end{abstract}

Keywords: Foot massage, Sleep disorder, Elderly

\section{PENDAHULUAN}

Lanjut usia adalah kelanjutan dari usia dewasa yang merupakan proses alami yang sudah ditentukan oleh Tuhan Yang Maha Esa (Nugroho, 2008). Akibatnya jumlah lanjut usia semakin bertambah dan cenderung lebih cepat dan pesat (Nugroho, 2006). Sistem tubuh pada lanjut usia akan mengalami penurunan diberbagai aspek baik biologis, fisiologis, psikososial, maupun spiritual yang merupakan suatu proses penuaan (Stanley $\&$ Beare, 2006).
Word Health Organization (WHO) mengatakan populasi lansia yang berusia diatas 60 tahun diperkirakan menjadi dua kali lipat dari $11 \%$ pada tahun 2000 dan akan bertambah menjadi 22\% tahun 2050 . Pada tahun 2000 penduduk lansia populasinya berjumlah 605 juta jiwa dan akan bertambah menjadi 2 miliar pada tahun 2050 (WHO, 2012). Berdasarkan hasil Susenas tahun 2013, jumlah lansia di Indonesia telah mencapai 20,40 juta orang atau sekitar $8,05 \%$ dari total penduduk Indonesia. Jumlah penduduk di Indonesia 
diperkirakan akan terus bertambah menjadi sekitar 450.000 jiwa per tahun.

Dengan demikian, jumlah penduduk lansia di Indonesia padatahun 2025 akan bertambah sekitar 34,22 juta jiwa (BPS, 2013). Semakin bertambahnya umur manusia, akan terjadi proses penuaan dengan diikuti berbagai permasalahan kesehatan terutama secara degeneratif yang berdampak pada perubahan-perubahan pada diri manusia baik dari perubahan fisik, kognitif, perasaan, sosial, dan seksual(Azizah, 2011). Perubahan-perubahan tersebut dapat menimbulkan berbagai macam gangguan, salah satunya adalah gangguan sulit tidur (insomnia). Lansia yang berusia diatas 65 tahun yang tinggal di rumah mengalami gangguan tidur sebesar 50\% dan lansia yang tinggal di fasilitas perawatan jangka panjang sebesar $66 \%$.

Lansia mengalami penurunan efektifitas tidur pada malam hari sebesar 70-80\% dibanding dengan usia muda, dimana 1 dari 4 lansia yang berusia 60 tahun atau lebih mengalami gangguan tidur (Adiyati, 2010). Menurut Widya (2010), insomnia merupakan suatu keadaan dimana seseorang sulit untuk tidur atau tidak dapat tidur dengan nyenyak.

Penanganan insomnia dapat dilakukan secara farmakologis dan non farmakologis. Penanganan secara farmakologis seperti obat-obatan hipnotik sedatif seperti Zolpidem, Tradozon, Lorazepam, Fenobarbital, Diazepam, Klonazepam, dan Amitripilin yang akan memiliki efek samping seperti gangguan koordinasi berfikir, gangguan fungsi mental, amnesia anterograd, ketergantungan, dan bersifat racun (Wiria, 2008). Sedangkan penanganan non farmakologis termasuk penanganan yang aman, efektif, dan tanpa efek samping seperti terapi komplementer yang termasuk terapi pengobatan alamiah.

Menurut National Institute of Health (NIH), terapi komplementer dikategorikan menjadi 5 yaitu : (1) Biological based practice : Herbal, vitamin dan suplemen lain, (2)Mind-body techniques : Meditasi, (3) Manipulative and body-based practice : Pijat (massage), refleksi (4) Energy therapies : Terapi medan magnet, (5) Ancient medical systems : Obat tradisional chinese, ayurvedic, akupuntur (Suardi, 2011). .

Terapi pijat (massage) merupakan tindakan manipulasi otot-otot dan jaringan dalam tubuh dengan tekanan, menggosok, dan vibrasi atau getaran dengan menggunakan sentuhan tangan, jari-jari tangan, sikut, kaki, dan alat-alat manual atau elektrik untuk memperbaiki kondisi kesehatan (Nurgiwiati, 2015).

Menurut penelitian yang dilakukan Aziz (2014), yaitu penelitian untuk mencari pengaruh terapi pijat (massage) terhadap tingkat insomnia pada lansia, dari penelitian tersebut didapatkan ada pengaruh yang signifikan antara terapi pijat (massage) terhadap tingkat insomnia pada lansia.

Berdasarkan hasil survey pendahuluan yang dilakukan oleh peneliti pada bulan Januari di Panti Wreda Dharma Bakti Kasih Surakarta bahwa jumlah lansia yang tinggal saat ini berjumlah 58 Lansia. Hasil wawancara yang dilakukan peneliti di Panti Wreda Dharma Bakti Kasih Surakarta terhadap 58 lansia didapatkan 25 lansia yang mengalami gangguan tidur.

Gangguan tidur yang dialami oleh para lansia tersebut seperti kesulitan untuk tidur, sering terbangun pada malam hari, dan kesulitan untuk tidur kembali. Upaya 
yang dilakukan oleh petugas kesehatan tersebut dalam menangani gangguan tidur adalah dengan pemberian obat tidur atau terapi farmakologis, sedangkan pemberian terapi farmakologis dalam waktu lama dapat memberikan efek yang tidak baik bagi kesehatan lansia yaitu seperti gangguan koordinasi berpikir, gangguan fungsi mental, amnesia anterograd, ketergantungan dan bersifat racun. Petugas kesehatan tersebut belum pernah memberikan pengobatan secara non farmakologis seperti masase kaki. Berdasarkan latar belakang diatas, masase dapat menurunkan insomnia pada lansia, maka peneliti tertarik untuk melakukan penelitian tentang : Pengaruh Foot Massage kaki terhadap kualitas tidur pada lansia di Panti Wredha Dharma Bakti Kasih Surakarta .

\section{METODE PENELITIAN}

Penelitian ini dilaksanakan di Panti Wredha Dharma Bhakti Kasih Surakarta pada bulan Mei - Juli 2018. Responden diminta ntk berpartisipasi dalam penelitian ini serta bersedia menandatangani Informmed consent. Responden merpakan Lansia dengan Total Sample. Kemdian dilakkan ramdomisasi sederhana dibagi 2 kelompok masing-masing terpilih 20 responden. Pada kelompok satu (intervensi) diberi tindakan dengan Foot Massage (pemijatan) pada kaki dengan rendam air hangat pada kaki sedangkan kelompok satunya (kontrol) diberi tindakan remdam kaki dengan air hangat. Selama penelitian berlangsung responden tidak ada yang droup out, sehingga semua responden dapat mengikuti penelitian sampai akhir.

\section{HASIL PENELITIAN}

Distribusi Kualitas Tidur Sebelum dan sesudah dilakukan Perendaman Kaki Pada Kelompok Kontrol di Panti Wredha Dharma Bakti Kasih Surakarta

Tabel 1. Distribusi Kualitas Tidur Sebelum dilakukan Perendaman Kaki Pada Kelompok kontrol di Panti Wredha Dharma Bakti Kasih Surakarta.

\begin{tabular}{cccccc}
\hline & & Frequency & Percent & $\begin{array}{c}\text { Valid } \\
\text { Percent }\end{array}$ & $\begin{array}{c}\text { Cumulativ } \\
\text { e Percent }\end{array}$ \\
\hline Valid & Buruk & 20 & 100.0 & 100.0 & 100.0 \\
\hline & Dari & 20 & responden & sebelum
\end{tabular}

dilakukan rendam, kaki mengalami kualitas tidur buruk sebanyak 20 responden.

Tabel 2. Distribusi Kualitas Tidur Sesudah dilakukan Perendaman Kaki Pada Kelompok kontrol di Panti Wredha Dharma Bakti Kasih Surakarta.

\begin{tabular}{cccccc}
\hline & Frequency & Percent & $\begin{array}{c}\text { Valid } \\
\text { Percent }\end{array}$ & $\begin{array}{l}\text { Cumulative } \\
\text { Percent }\end{array}$ \\
\hline \multirow{3}{*}{ Valid } & Baik & 6 & 30.0 & 30.0 & 30.0 \\
\cline { 2 - 6 } & Buruk & 14 & 70.0 & 70.0 & 100.0 \\
\cline { 2 - 6 } & Total & 20 & 100.0 & 100.0 & \\
\hline \multirow{4}{*}{ Dari } & 20 & responden & setelah
\end{tabular}

diberikan tindakan remdam kaki mengalami peningkatan kualitas tidur, dari 20 responden yang mengalami kualitas tidur buruk menajadi 6 yang mengalami kualitas tidur baik dan 14 mengalami kualitas tidur buruk.

Tabel 3. Pengaruh Perendaman Kaki terhadap Kualitas tidur lansia di Panti Wredha Dharma Bakti Kasih Surakarta

\begin{tabular}{lc}
\hline & $\begin{array}{c}\text { Potest_Kontrol - } \\
\text { Pretest_Kontrol }\end{array}$ \\
\hline $\mathrm{Z}$ & $-2.214^{\mathrm{b}}$ \\
\hline Asymp. Sig. (2-tailed) & .027 \\
\hline $\begin{array}{l}\text { a. Wilcoxon Signed Ranks Test } \\
\text { b. Based on positive ranks. }\end{array}$
\end{tabular}


Tidak ada pengaruh perendaman Kaki terhadap kualitas tidur pada lansia di Panti Wredha Dharma Bakti Kasih Surakarta di tunjukkan oleh angka 0,027 > 0,005 yang artinya tidak signifikan.

Distribusi Kualitas Tidur Sebelum dan sesudah dilakukan Pemijatan dan Perendaman Kaki Pada Kelompok Intervensi di Panti Wredha Dharma Bakti Kasih Surakarta

Tabel. 4. Distribusi Kualitas Tidur Sebelum dilakukan Pemijatan dan Perendaman Kaki Pada Kelompok Intervensi.

\begin{tabular}{cccccc}
\hline & Frequency & Percent & $\begin{array}{c}\text { Valid } \\
\text { Percent }\end{array}$ & $\begin{array}{c}\text { Cumulative } \\
\text { Percent }\end{array}$ \\
\hline Valid & Buruk & 20 & 100.0 & 100.0 & 100.0 \\
\hline & Dari & 20 & responden & $(100 \%)$
\end{tabular}

sebelum diberikan tindakan Foot Massage Semua mengalami kualitas tidur yang buruk.

Tabel 5. Distribusi Kualitas Tidur Setelah dilakukan Pemijatan dan Perendaman Kaki Pada Kelompok Intervensi.

\begin{tabular}{cccccc}
\hline & & Freq & Percent & $\begin{array}{c}\text { Valid } \\
\text { Percent }\end{array}$ & $\begin{array}{c}\text { Cumulative } \\
\text { Percent }\end{array}$ \\
\hline \multirow{3}{*}{ Valid } & Baik & 9 & 45.0 & 45.0 & 45.0 \\
\cline { 2 - 6 } & Buruk & 11 & 55.0 & 55.0 & 100.0 \\
\cline { 2 - 6 } & Total & 20 & 100.0 & 100.0 & \\
\hline
\end{tabular}

Dari 20 responden (100\%) setelah diberikan tindakan Foot Massage mengalami peningkatan kualitas tidur dari 20 responden $(100 \%)$ yang mengalami kualitas tidur buruk menjadi 9 (45\%) yang mengalami kalitas tidur baik dan $11(55 \%)$ mengalami kualitas tidur buruk.
Tabel 6. Pengaruh Pemijatan dan Perendaman Kaki terhadap Kualitas tidur lansia di Panti Wredha Dharma Bakti Kasih Surakarta.

\begin{tabular}{lc}
\hline & $\begin{array}{l}\text { Postest_Intervensi } \\
\text { Pretest_Intervensi }\end{array}$ \\
\hline $\mathrm{Z}$ & $-3.225^{\mathrm{b}}$ \\
\hline $\begin{array}{l}\text { Asymp. } \\
\text { tailed) }\end{array}$ & Sig. $\quad(2-.001$ \\
\hline
\end{tabular}

Ada pengaruh foot massage (pemijatan) dan perendaman Kaki terhadap kualitas tidur lansia di Panti Wredha Dharma Bakti Kasih Surakarta di tunjukkan oleh angka $0,001<0,005$ yang artinya signifikan.

Hasil uji Wilcocxon terhadap kualitas tidur pada pada Kelompok Intervensi dan Kelompok Kontrol pada Lansia di Panti Wredha Dharma Bakti Kasih Surakarta.

Tabel 7. Pengaruh foot massage dan perendaman kaki terhadap kualitas tidur Pada Kelompok Intervensi dan kelompok kontrol di Panti Wredha Dharma Bhakti Kasih Surakarta

\begin{tabular}{ll}
\hline & Kualitas Tidur \\
\hline Mann-Whitney U & 93.500 \\
\hline Wilcoxon W & 303.500 \\
\hline$Z$ & -2.933 \\
\hline Asymp. Sig. (2-tailed) & .003 \\
\hline Exact Sig. [2*(1-tailed $.003^{\mathrm{b}}$ \\
Sig.)] \\
\hline \multicolumn{2}{l}{ Berdasarkan Tabel 7 diperoleh }
\end{tabular}
data hasil uji Wilcocxon dengan probabilitas 0,003 dengan kriteria $P<$ 0,05 , sehingga terjadi perubahan kualitas tidur pada Lansia ditunjukkan oleh angka $0.003<0,05$ yang artinya Ha diterima dan Ho ditolak. 


\section{PEMBAHASAN}

Kualitas Tidur sebelum dan sesudah dilakukan perendaman kaki pada kelompok kontrol di Panti Wredha Dharma Bakti Kasih Surakarta. Dari hasil penelitian didapatkan bahwa 20 orang $(100 \%)$ dari total responden mengalami kualitas tidur buruk sebelum melakukan terapi perendaman dengan air hangat pada kaki, dan 6 orang $(30 \%)$ diantaranya sudah memiliki kualitas tidur baik setelah melakukan terapi air hangat, dan 14 orang $(70 \%)$ masih memiliki kualitas tidur buruk. Gangguan tidur merupakan keadaan terputusnya tidur yang mana pola tidur-bangun berubah dari pola kebiasaannya, hal ini menyebabkan penurunan kuantitas dan kualitas tidur. Gangguan tidur yang dialami oleh respoden antara lain bangun tidur ditengah malam atau bangun terlalu cepat, pergi ke kamar mandi dimalam hari, dan merasa pegal-pegal.

Berdasarkan hasil analisa menurut

Wilcoxon Signed Rank test bahwa pengaruh perendaman kaki terhadap kualitas tidur pada Lansia Di Panti Wredha Dharma Bakti Kasih Surakarta ditunjukkan oleh angka angka 0,027 > 0,005 yang artinya tidak signifikan. Penelitian ini menandakan bahwa tidak adanya pengaruh terapi perendaman dengan air hangat terhadap kualitas tidur pada lansia, karena jumlah lansia yang mengalami kualitas tidur buruk sudah berkurang, tetapi jika kita lihat Kualitas tidur lansia didapatkan dari kualitas tidur subyektif, latensi tidur, durasi tidur, efisiensi kebiasaan tidur, gangguan tidur dan penggunaan obat tidur. Keluhan mengenai kesulitan tidur pada waktu malam hari seringkali terjadi diantara usia lanjut, biasanya akibat keberadaan penyakit kronik yang lain misalnya arthritis. Kecenderungan untuk tidur siang kelihatannya meningkat secara progresif dengan bertambahnya usia. Peningkatan waktu tidur di siang hari dapat terjadi karena seringnya terbangun pada malam hari (Potter \& Perry, 2005)

Kualitas Tidur sebelum dan sesudah dilakukan pemijatan ( Foot Massage) dan perendaman kaki pada kelompok Intervensi di Panti Wredha Dharma Bakti Kasih Surakarta.

Hasil penelitian menunjukkan bahwa pemijatan kaki mempengaruhi kualitas tidur pada lansia. Dari hasil penelitian didapatkan bahwa 20 orang (100\%) dari total responden mengalami kualitas tidur buruk. Penyebab responden masih memiliki kualitas tidur buruk yaitu cemas, masih memiliki durasi tidur $<5$ jam, latensi tidur yang lama, gangguan tidur, sering menguap atau mengantuk. Latensi tidur adalah durasi mulai dari berangkat tidur sampai tertidur.

Seseorang dengan kualitas tidur yang baik menghabiskan $\leq 15$ menit sejak orang tersebut dapat memasuki tahap tidur selanjutnya secara lengkap dan cepat. Setelah dilalukan pemijatan pada kaki, 9 orang $(45 \%)$ diantaranya sudah memiliki kualitas tidur baik dan 11 orang $(55 \%)$ masih memiliki kualitas tidur buruk. Penelitian ini menandakan bahwa ada pengaruh terapi pemijatan terhadap kualitas tidur pada lansia, karena jumlah lansia yang mengalami kualitas tidur buruk sudah berkurang.

Kualitas tidur lansia didapatkan dari kualitas tidur subyektif, latensi tidur, durasi tidur, efisiensi kebiasaan tidur, gangguan tidur, penggunaan obat tidur, gangguan aktivitas di siang hari menunjukkan perubahanan yang signifikan. Berdasarkan hasil analisa menurut Wilcoxon Signed Rank test 
bahwa pengaruh pemijatan pada kaki terhadap kualitas tidur pada Lansia Di Panti Wredha Dharma Bakti Kasih Surakarta ditunjukkan oleh angka angka $0,001<0,005$ yang artinya signifikan.

Secara fisiologi didaerah kaki terdapat banyak syaraf terutama di kulit yaitu flexus venosus dari rangkaian syaraf ini stimulasi diteruskan ke kornu posterior kemudian dilanjutkan ke medula spinalis, dari sini diteruskan ke lamina I, II, III Radiks Dorsalis, selanjutnya ke ventro basal talamus dan masuk ke batang otak tepatnya di daerah rafe bagian bawah pons dan medula disinilah terjadi efek soparifik (ingin tidur). Banyak cara yang dapat digunakan untuk menanggulangi masalah tidur. Salah satunya adalah terapi relaksasi yang termasuk terapi nonfarmakologi. Salah satunya adalah terapi pemijatan atau terapi relaksasi.

Hal lain yang dapat mempengaruhi hasil penelitian seperti kebiasaan mengkonsumsi kafein atau kebiasaan merokok. Berdasarkan hasil wawancara dengan seluruh responden didapatkan data bahwa responden tidak mempunyai kebiasaan merokok ataupun mengkonsumsi kafein. Beberapa manfaat foot massage menunjukkan bahwa foot massage merupakan elemen yang mudah dan memiliki pengaruh besar. Menurut Trisnowiyanto (2012) dengan memberikan massage pada area kaki dapat memperlancar sistem peredaran darah, karena pijatan memberikan efek kenyamanan, sedatif dan mampu merangsang sistem syaraf dan meningkatkan aktifitas otot, sehingga pijatan pada kaki dapat mengendurkan otot-otot yang membuat pasien menjadi relaks.

Menurut Oshvandi, Abdi, Karampourian, Moghimbaghi, \&
Homayonfar (2014) massage pada kaki memberi manfaat mengurangi kecemasan, stress dan nyeri yang dirasakan oleh pasien, sekalipun massage yang diberikan dalam waktu yang pendek dan hanya pada bagian kaki saja, dapat memberikan manfaat hati menjadi lebih tenang, stress berkurang dan peningkatan pada tidur. Dengan demikian intervensi foot massage yang diberikan pada responden di Panti Wredha meliputi gerakan sentuhan, pijatan serta mengurut kaki bagian bawah secara sistemik dan ritmik akan mengurangi ketegangan otot, menciptakan suasana relaks yang pada akhirnya dapat memperbaiki kualitas tidur.

\section{KESIMPULAN DAN SARAN}

1. Tingkat kualitas tidur lansia di Panti Wreda Dharma Bakti Kasih Surakarta sebelum dilakukan foot massage dan perendaman kaki dengan air hangat semua mengalami kualitas tidur buruk, yaitu sejumlah 20 orang.

2. Tingkat kualitas tidur lansia di Panti Wreda Dharma Bakti Kasih Surakarta pada kelompok kontrol setelah dilakukan perendaman kaki dengan air hangat hasilnya ada peningkatan tetapi tidak signifikan dengan nilai $\mathrm{P}=0,27$ ( $>0.005$ ), sedangkan pada kelompok intervensi setelah dilakukan foot massage dan perendaman kaki dengan air hangat, hasilnya mengalami peningkatan yang signifikan dengan niali $\mathrm{P}=0.001(<0.005)$. 3 . Terdapat pengaruh foot massage dan rendam air hangat pada kaki terhadap peningkatan kualitas tidur.

Penelitian menunjukkan bahwa pemberian masase dan rendam air hangat dapat menurunkan tingkat insomnia pada lansia. Hasil penelitian ini dapat dijadikan acuan lansia untuk dapat lakukan secara 
mandiri ketika mereka mengalami kesulitan tidur.

Pengurus panti hendaknya menyediakan sarana dan prasarana yang dapat mendukung upaya penurunan tingkat insomnia pada lansia. Penurunan tingkat insomnia lansia berarti bahwa kualitas tidur lansia meningkat sehingga kesehatan lansia lebih meningkat.

Penelitian selanjutnya dapat menggunakan penelitian ini sebagai acuan untuk melakukan penelitian lanjutan, misalnya dengan menggunakan intervensi lainnya atau mencari faktor-faktor apakah yang berhubungan dengan penurunan tingkat insomnia lansia.

\section{DAFTAR RUJUKAN}

Adiyati, S. (2010). Pengaruh Aromaterap Terhadap Insomnia Pada Lansia di PSTW Unit Budi Luhur Kasongan Bantul Yogyakarta. Jurnal Kebidanan. Vol. II. No. 02.

Amir, N. (2007). Ganguan Tidur Pada Lansia, Diagnosis Dan Penatalaknsanaan. Cermin Dunia Kedokteran No. 15: 196-206.

Astuti, N. M. H. (2013). Penatalaksanaan Insomnia Pada UsiaLanjut. Bagian/SMF Psikiatri Fakutas Kedokteran Universitas Udayana/Rumah Sakit Pusat Sanglah Depasar.

Aziz, M. T. (2014). Pengaruh Terapi Pijat (Massage) Terhadap Tingkat Insomnia Pada Lansia di Unit Rehabilitasi Sosial Pucang Gading Semarang.

Azizah, M. L. (2011). Keperawatan Lanjut Usia. Yogyakarta : Graha Ilmu. 